\title{
2 \\ A New Cold War? Implications for the Pacific Islands ${ }^{1}$
}

\author{
Terence Wesley-Smith
}

In 2012 former president of Kiribati Anote Tong welcomed increased interest in the Pacific Islands by external powers, commenting that it is 'nice to be relevant' (Tong 2015). He also noted significant changes in the way that leaders were dealing with outside forces impacting the region, a shift that Greg Fry and Sandra Tarte argued represented a 'new Pacific diplomacy'. Characterised by an emphasis on self-determination exercised through new institutions and focused on addressing relevant global issues, particularly climate change, Fry and Tarte identified 'a time of transformation of the regional diplomatic culture equivalent to the move from the colonial to the postcolonial era, a time that represents a transformation of regional order' (Fry and Tarte 2015:4). Yet just a few years later, the region appears to be entering another transition occasioned by the very geopolitical changes welcomed by President Tong and associated with the expanding influence of China.

Until recently, commentators have been sanguine about the impact ofChina's growing presence in the region, noting advantages such as new diplomatic, trade and investment opportunities for Pacific Island states (see, for example,

1 Many thanks to Greg Fry and Graeme Smith for their very useful comments and suggestions on an earlier version of this chapter. 
D’Arcy 2016; Wesley-Smith 2013, 2016). These sentiments were not necessarily shared by representatives of more established external actors in the region, particularly Australia, New Zealand and the United States, worried about erosion of their longstanding influence in regional affairs. Nevertheless, officials adopted a generally pragmatic attitude, perhaps swayed by China's preference for working within established economic and political systems rather than attempting to replace them. In 2012, then US secretary of state Hillary Clinton told a news conference in Cook Islands that the Pacific 'is big enough for all of us' and went on to say, 'We think it is important for the Pacific Island nations to have good relationships with as many partners as possible, and that includes China as well as the United States' (Dziedzic 2012).

Two main factors have conspired to upset Clinton's attitude to regional developments. First, China has embarked on a more assertive and ambitious phase in its rise to global power. In 2017, five years into his tenure as Communist Party General Secretary, President Xi Jinping announced that China had 'crossed the threshold into a new era' (McCahill 2017:2). Buoyed by constitutional changes consolidating his hold on domestic power, Xi Jinping's 'Chinese Dream' imagines a proud China restored to its former status as a global actor, pursuing its interests through expanded networks of trade and diplomacy backed by a rapidly modernising military. Xi's signature diplomatic and economic program, now known as the Belt and Road Initiative (BRI), is massive in scale and aspiration. His attitude to the eventual reintegration of Taiwan has hardened considerably and his actions in the South China Sea, including building militarised artificial islands, leave no doubt about China's determination to establish 'a maritime sphere of influence with exclusive rights to resources' in what China terms its 'near seas' periphery (Roy 2014). There are clear signs in all of these developments that Beijing is now prepared to challenge a global order long dominated by the United States, at least when it considers it necessary to do so.

Second, and of more immediate importance, existing power holders have responded more forcefully to the challenges of China's rise. US President Obama's administration recognised the significance of developments in China for American power and attempted to counter them through a strategic 'pivot' to the Asia-Pacific region, as well as efforts to consolidate US relations with regional countries, particularly through the Trans-Pacific Partnership trade agreement. But the Trump administration abandoned any pretence at soft balancing and labelled China a strategic rival and 
evil actor. A report to the US Congress in November 2018 declared that 'many aspects of China's attempts to seize leadership have undoubtedly put at risk the national security and economic interests of the United States, its allies, and its partners' (USCC 2018:vii). In a speech to the Hudson Institute the previous month, Vice President Mike Pence roundly condemned Beijing's authoritarian domestic activities and expansionist aspirations and promised 'strong and swift action' in response to any violations of international norms (Pence 2018). As Zachary Karabell points out, Pence's remarks were reminiscent of Churchill's 1946 Iron Curtain speech signalling the start of the Cold War with the Soviet Union (2018:1). Indeed, it has become commonplace for US officials and commentators to talk of the escalating US-China contest as 'nothing less than a new cold war', even if their understanding of what that means differ (Kaplan 2019:2; see also Tarabay 2018; White 2019). Whatever its characteristics, as Stephen Walt argues, this 'will be the single most important feature of world politics for at least the next decade and probably well beyond that' (2018:3).

This chapter explores some implications of these geopolitical developments for the Pacific Islands, and particularly for president Tong's vision of a region striving to 'chart its own course' (Tong 2015:24). It is worth noting that the impacts on the region of the Cold War with the Soviet Union were profound, shaping the process of decolonisation in significant ways, and establishing patterns of 'development assistance' (and aid dependency) that persist to this day. Although Fry argues that US, British and French nuclear testing programs in the region would have proceeded regardless, Cold War dynamics enhanced their importance, with catastrophic consequences for some island populations (Fry 1993:227-29). The underlying rationale for Western foreign policy initiatives towards the region for most of this period was strategic in nature, designed to keep newly independent island states 'on side' and completely exclude the Soviet Union from regional affairs. ${ }^{2}$

The impact of US-China rivalry on the Pacific Islands will be different because its inherent characteristics are different, because China is already deeply involved in the region and because the region is unlikely to be a primary site of geopolitical confrontation. Nevertheless, the spillover

2 Even at the height of the Cold War, Pacific Islander agency helped determine regional outcomes: for example, when the Western allies were forced to modify their ideas about strategic denial after Kiribati (1985) and Vanuatu (1987) signed fisheries access agreements with the Soviet Union (Fry 1993:232-35). 
effects from major zones of friction, such as the jurisdictional disputes in the South China Sea, or the struggle for control of Taiwan, are already apparent. Meanwhile, the most immediate impacts are economic and diplomatic, as the US and allies such as Australia, New Zealand, the United Kingdom, France, the EU and Japan ratchet up their own regional activities. Western interest increased dramatically in 2018 when analysts worried that China would use debt-derived leverage to establish a military presence in the region. The main impetus for Australia's 'Step-Up', New Zealand's 'Pacific Reset' and the US's 'Pacific Pledge' initiatives is again strategic. These priorities for the Western allies sets them at odds with those of their island partners who have determined that climate change, not a rising China, is the major threat to regional security. While these new levels of interest and sources of economic support are welcomed by Island leaders, the challenge will be to use them to achieve the sustainable forms of development they have espoused in recent years. Even if these domestic efforts are successful, the serious threats posed by climate change are likely to intensify, propelled in part by the race for economic growth at the heart of the US-China confrontation. If this is a new Cold War, it is taking place in and contributing to a warming world.

\section{A new Cold War?}

The US-dominated international order faces challenges on two main fronts: from Russia and its surrogates in Europe and the Middle East, and from Beijing along China's maritime peripheries, with China regarded as the more formidable opponent by far. As Hugh White notes, China 'is the strongest adversary America has ever faced, and getting steadily stronger' (2019:5). Furthermore, according to Robert Sutter, the 'partnership between China and Russia has matured and broadened ... with serious consequences for US interests' (2018:3).

There are significant differences between the emerging US-China standoff and the Cold War. Perhaps most notable is the role of ideology, a central feature of conflict with the Soviet Union. Clearly there are ideological differences between the two sides, with the US espousing liberal democratic principles and China remaining committed to Communist Party rule and a managed economy. ${ }^{3}$ The US is the main proselytiser, constantly seeking

3 It is interesting to note that a group of Trump allies and leaders in conservative thought have recently revived the Cold War-era Committee on the Present Danger to counter China's 'existential and ideological threat to the United States and to the idea of freedom' (Spinelli 2019). 
to promote its political values overseas aided by a dominant discourse that frames liberal ideas, such as the so-called Washington consensus for development initiatives, as self-evident. Indeed, one factor fuelling the new hostility towards China is that Beijing has not implemented the liberal reforms that Western commentators argue should accompany economic growth. Instead, the Communist Party 'has used economic growth ... to strengthen its own grasp on authority ... [and] advance its state-capitalist model' (USCC 2018:vii). Even if some Chinese leaders now refer to 'the China model' and President Xi routinely cites a 'community of common destiny' when discussing BRI, to date Beijing has not systematically tried to persuade its diplomatic and trade partners to adopt China's approach to governance or economic development (Callahan 2016). China has consistently refrained from commenting on the internal affairs of countries in the Global South, even if that leaves Beijing open to accusations of encouraging authoritarian or rogue regimes overseas.

Also in contradistinction to the Soviet example, China has risen to power precisely by working within the US-dominated economic and political order. Rather than two largely autonomous systems separated by an 'iron curtain', the economies of the US and China are deeply entangled, with extensive corporate and people-to-people exchanges between the countries. As Peter Frankopan notes:

Asia and the Silk Roads are rising — and they are rising fast. They are not doing so in isolation from the West, nor even in competition with it. In fact, quite the opposite: Asia's rise is closely linked with the developed economies of the United States, Europe and beyond (2019:24).

Many countries now have significant trade, aid or investment ties to China, even those with strained political relationships to Beijing, like Japan, Vietnam or Taiwan, or firm strategic allies of the United States anxious about China's increased global influence, such as Australia and New Zealand.

Another significant difference between the emerging situation and the Cold War lies in its military dimensions. The Cold War involved an escalating arms race precipitating the 1962 Cuban missile crisis that brought the world to the brink of nuclear war, as well as bloody proxy wars in Korea, Indochina and Afghanistan (Lind 2018:2). Although China possesses nuclear weapons too, which would hopefully prevent cold war conflict becoming hot, the current situation is quite different (but see 
Talmadge 2018). Beijing has devoted considerable resources to expanding and modernising its military apparatus and particularly the blue-water capacity of its navy, but it is building from a low base. The Liaoning, its first aircraft carrier, launched in 2012, is an older refurbished vessel of Soviet design; a second, domestically produced vessel, the Shandong, was commissioned in December 2019. Perhaps China's most notable achievements in military technology are the development of stealth aircraft that can reportedly match US models in performance and an increasing capacity for cyber warfare. However, it is worth remembering that in 2018 Washington devoted approximately 2.5 times more in absolute terms in support of the military than Beijing (SIPRI 2019). Western analysts acknowledge that it will be many years before China can match American military might and global reach, although they express concern about Beijing's growing digital and artificial intelligence capabilities and asymmetric ability to disrupt US military operations. In any case, given the enormous demand for resources at home, Beijing may have no immediate ambitions to mount such a global challenge. As Georgetown University's Oriana Mastro argues, 'China has no interest in establishing a web of global alliances, sustaining a far-flung global military presence, sending troops thousands of miles from its borders' (2019:2).

Unlike much of the Cold War struggle, the military dimensions of the emerging US-China rivalry are asymmetric and concentrated in key geographic areas, most notably the near seas periphery, control of which China regards as essential to its national security. Western officials are conscious of the fact that China already has the wherewithal to disrupt US naval activities and challenge the 'rules-based order' in the western Pacific; hence a new emphasis on the so-called Indo-Pacific strategy to shore up US relations with allied countries in East, Southeast, and South Asia, and the revival in 2017 of the informal Quadrilateral Security Dialogue ('the Quad') between the US, Japan, Australia and India, with a shared commitment to 'defend their vision of regional order against what they perceived as accelerating Chinese aggression' (Tarapore 2018:2; US Government 2019). As it attempts to protect itself against what Beijing perceives as US attempts to encircle and contain its rise, China seeks to displace the US as the dominant power in Asia. As Mastro puts it, 'Although China does not want to usurp the United States' position as the leader of a global order ... it wants to force the US out [of Asia]' (2019:2). 
In essence, then, for the moment at least, 'this is a contest ... between the world's two most powerful states over the leadership of the world's most prosperous and dynamic region' (White 2019:4).

The fundamental concern among Western analysts is that China's growing economy not only enables its military expansion but also threatens US economic superiority and ability to influence global events through non-military means. As Jude Woodward argued, 'The relative decline of the US economy meant that it has less capacity to use economic leverage alone to bind countries across the developing world to its strategic priorities' (2017:5). These concerns are exacerbated by fears that US technological superiority is being eroded. The focus of the Trump regime was apparently on curbing aberrant Chinese trade practices through hefty sanctions. But the underlying worry was Beijing's rapid transition from an economy built around labour-intensive industries to one driven by China-controlled advanced technology, 'the real existential threat to US technological leadership' (Laskai 2018:2). These trends and perceptions increase the likelihood of armed conflict. As Woodward argued, 'The US's declining economic leverage means it is forced to rely more openly on military means to achieve many of its objectives' (2017:11).

In Beijing, much of this is seen as US attempts to prevent China achieving its destiny as a great power. Beijing's military build-up is understood as defensive, largely consisting of targeted efforts to establish control of vital trade routes that represent China's lifelines for continued economic growth, thereby reducing dependency on the exceptional global reach of the US navy. This need to establish control explains the establishment of Beijing's first overseas military base in Djibouti in the Horn of Africa where busy sea lanes converge, as well as the focus on China's maritime periphery-its near seas-where a large proportion of its global trade is concentrated. The renewed focus on Taiwan as a renegade province and its eventual reintegration into China is emblematic of the heightened nationalism encouraged by President $\mathrm{Xi}$, but it also reflects a pragmatic recognition of the island's strategic location just a few miles off China's coast. Beijing regards its diplomatic and economic initiatives in neighbouring Asian countries as legitimate attempts to counter threats from an encircling network of US military bases in Japan, South Korea, Guam, Singapore and Australia, from staging areas in other countries such as the Philippines and a US-supported arms build-up in Taiwan. 
None of this is to diminish the importance of the growing rivalry between these great powers, or potential spillover effects in the Pacific Islands, but rather to note that some of its manifestations are different from the conflict with the Soviet Union. In particular, this is not so much a zerosum battle for ideological control of the global order as a rivalry where Beijing's challenges to the status quo are selective and where complex economic and political dimensions overlap. At least for the moment, other countries, including the Pacific Islands, find themselves dealing with both parties and attempting as best they can to balance strategic, political or commercial imperatives, although choosing one side or the other may well become necessary as the conflict intensifies (White 2017; see also Wesley-Smith and Smith, Introduction to this volume). The initial focus of the competition is on Asia, although other fronts may open up in time. ${ }^{4}$ For most parts of the world, particularly the developing countries of the Global South, this will be a struggle for influence fought largely with trade deals, defence agreements, infrastructure projects and financial incentives.

As with the Cold War, economic growth is at the centre of US-China competition, representing the very essence of China's rise as well as the key to US attempts to retain its global power. In another similarity with the Cold War, the main instrument deployed in the competition for influence in the developing world, including the Pacific Islands, is the promise of economic development. But unlike the earlier period, all of this is playing out in the face of a mounting climate change crisis and a growing realisation that, despite the breakthrough 2015 Paris Agreement, the global community is incapable or unwilling to do enough to curb emissions (see, for example, Harvey 2019). George Monbiot argues that economic growth is the fundamental and often-ignored factor in the fight against climate change: 'Beyond a certain point, economic growth-the force that lifted people out of poverty, and cured deprivation, squalor and disease-tips us back into those conditions' (2018). After reviewing the results of recent studies about the growth-emissions relationship, economist Peter Christensen concludes that the implication is that:

4 In December 2018, then national security advisor John Bolton announced a new US-Africa strategy designed to counter what he described as China's corrupt and predatory practices on that continent (Bolton 2018). 
If we are producing more and consuming more, we must assume that emission rates will grow significantly faster than we thought. Our current estimates of future damages are highly sensitive to growth rates and the primary reason is that is what's driving emissions. In the absence of meaningful climate policy, higher baseline growth scenarios likely imply higher emissions growth around the world (quoted in Yale News 2018).

As will be discussed further below, in this context the emergence of USChina competition must be regarded as a particularly ominous turn of events.

\section{Pacific spillover}

In May 2014 President Xi Jinping sent a veiled warning to Washington when he told a regional security forum in Shanghai that Asia's security problems should be solved by Asians themselves (China Daily 2014). The focus here is on the Asia part of the Asia-Pacific region and, even if Beijing regards the Pacific Islands as part of China's 'great periphery' or extended neighbourhood, and has included it in the BRI, there is no strong evidence that it has been singled out for special attention even in President Xi's 'new era' (Zhang 2018:7). China's trade, aid, investment and diplomatic activities in the Pacific Islands region have increased significantly in recent years, but no more so than elsewhere in the world. Nevertheless, several overlapping sites of escalating US-China tensions in Asia have connections with, or implications for, Pacific Island countries. These tensions include the increased militarisation of the wider region, the disputes in the South China Sea and the struggle over Taiwan's political status.

The military dimensions of the US pivot to Asia include increased air and naval capacity in the region, regular naval forays into disputed areas along China's coastline, advanced missile systems in South Korea, US troops stationed in Darwin, Australia, and enhanced access arrangements in Southeast Asian countries, particularly the Philippines. China's activities, in turn, represent what US analysts call 'Area Access/ Area Denial' (A2/AD), involving 'shore-based ground-to-air, anti-ship and air defense missiles, improved fighter aircraft, radar and tracking' to create a protective umbrella over its naval operations in the near seas (Woodward 2017:72). 
The most immediate impact of these developments in the Pacific Islands region is in Guam, a US territory and home to major military installations. ${ }^{5}$ In recent years the militarisation of Guam has intensified significantly, with the planned relocation of large number of US military personnel from bases in Okinawa, the construction of facilities for these additional troops, a new deep-draft wharf to accommodate aircraft carriers and a training facility to improve Guam's capacity to intercept intercontinental ballistic missiles (Aguon 2010:65-66). Not only does all of this make Guam more vulnerable to missile attack in the event of conflict, but also it serves to deepen the social and political marginalisation of the island's indigenous people. Even before the current build-up, Chamorro represented less than 40 per cent of the resident population, a demographic disadvantage that will be exacerbated even if only a portion of the projected influx eventuates. Guam is one of the 17 remaining entities on the United Nations' (UN) list of Non-SelfGoverning Territories and, despite a recent UN resolution condemning the use of such territories for military purposes, Guam's central role in the pivot must be seen as a further setback for the longstanding movement for self-determination there (Aguon 2010).

The military spillover may also have a potential impact on three USaffiliated entities, parts of which make up what strategists call the 'second island chain': the Republic of the Marshall Islands (RMI), the Federated States of Micronesia (FSM) and the Republic of Palau (ROP). These strategically significant islands were taken over by the US after the defeat of Japan in World War II and gained qualified forms of independence in 1986 (RMI and FSM) and 1994 (ROP). Their ongoing relationships with the US are defined by compacts of free association (COFA) that allow for financial support and access to the US for COFA citizens in return for complete strategic control of these entities by Washington. As a US State Department official noted in 2003, 'The most significant US interest at the time the Compact was negotiated was the value placed on the right to exercise strategic denial over half a million square miles of the Pacific between Hawaii and Guam' (in Underwood 2017:4). Although the compacts and subsidiary agreements also allow for military installations, if Washington deems them necessary, to date the only permanent military facility is the Kwajalein missile-testing facility in the Marshall Islands.

5 The neighbouring Northern Mariana Islands, a commonwealth in political union with the US, is also impacted but to a lesser extent. 
The importance of the test site has increased with the growing emphasis on missile defence systems and two new radar systems capable of monitoring Chinese air and naval activities (as well as North Korean missiles) are being installed in Palau. Former president of Palau Johnson Toribiong recently observed that the US presence 'is more recognizable in Palau now' and describes this trend, as well as the eventual authorisation of long-delayed compact funding in the US Congress, as 'in part a reaction to the presence of China in the South China Sea' (Kerrigan 2018:2).

For RMI and FSM, the first periodic renegotiations occurred in 2003 and the new agreements, known as Compact II, entered into force in 2004. These reviews occurred in the period after the end of the Cold War and before the China threat had emerged as a major preoccupation in Washington, which may account for the relatively harsh terms insisted on by US negotiators. At the time, the Government Accounting Office concluded that the value of strategic denial was overrated in the postCold War world; Robert Underwood commented that a heavy emphasis on US financial oversight made Compact II 'more compact and less free' (2017:9). The funding for Palau's latest compact was agreed upon in September 2010 but not released by Congress until March 2018, also indicating lack of interest in Washington. However, in June 2018, the US-China Economic and Security Review Commission reported increased 'concern that the US Compact countries could decide to end their agreements with the United States, in part due to China's increased influence' and indeed such a move has already been proposed in the FSM legislature (Meick et al. 2018:19). This suggests that the compact states will go into the next set of negotiations, which have to occur before 2023 (2024 for Palau), with more leverage than before. A notable part of Washington's recent Pacific Pledge initiative is increased interest in the freely associated states. In May 2019, President Trump met the leaders of these states in the White House and, in another first, Secretary of State Mike Pompeo followed up with a further high-level meeting in Pohnpei in FSM in August.

Although Underwood is confident that the compacts will be renegotiated, the China factor has rendered this outcome less certain that it would have seemed just a few years ago (Grossman et al. 2019; Underwood 2017:10). It will be interesting to see whether exclusion of foreign military from the compact states continues to be the operating principle for US planners, or if further militarisation of these islands begins to replace strategic denial 
as US-China competition intensifies. Perhaps as a sign of things to come, in April 2019 US soldiers took part in training exercises in Palau, the first such deployment in more than 30 years (Olson 2019).

Military dimensions of the emerging conflict are also manifest elsewhere in the region. France has used the rise of China to justify maintaining a modest military presence in New Caledonia although, as Nic Maclellan argues, its possible role in the event of conflict in the distant South China Sea remains unclear (see Maclellan, Chapter 6). More significant are Australia's recent actions, triggered by concerns that China is seeking to establish a naval presence in the region. Although such speculation is not new, the narrative catapulted to prominence with a story in The Sydney Morning Herald in April 2018 claiming that a project to upgrade the Luganville wharf on the island of Espiritu Santo in Vanuatu, funded by Chinese loans, could accommodate Chinese naval vessels. The story quoted 'senior security officials' to suggest that this initiative might 'culminate in a full military base' (Wroe 2018). Despite emphatic denials from officials in Vanuatu and China, and the fact that the story's claims were never publicly substantiated, then prime minister Malcolm Turnbull warned that Canberra would view 'with great concern' the establishment of any military bases in the region (ABC News 2018).

Much of Canberra's Step-Up effort is economic, ostensibly designed to help Pacific Island countries avoid the 'debt trap diplomacy' associated with Chinese-funded infrastructure projects, but several initiatives are strategic in nature. Canberra has substantially increased its funding for the Australian Defence Cooperation Program in Papua New Guinea (PNG), launched a AU\$2 billion Pacific Maritime Security Program, agreed to redevelop Fiji's Black Rock Camp as a regional hub for police training and proposed new security cooperation agreements with Vanuatu and Solomon Islands (Morgan 2018). Perhaps most significantly, in November 2018, Australia reached agreement with PNG to build a joint naval base on Manus Island, rehabilitating a facility used by the US in World War II. This followed reports that Chinese companies had expressed interest in helping develop the port ${ }^{6}$ and speculation that, like the Luganville wharf, it could be used as 'an ideal logistics node for China's People's Liberation Army-Navy ... as it seeks to sustain more frequent operations in the Western Pacific' (Panda 2018).

6 There was speculation that China Harbour Engineering, which was already developing Manus's Momote Airport, was interested in port construction on Manus (Jaipragas 2018). 
The Lombrum Naval Base initiative, also supported by the US, is significant not only because it provides PNG with an upgraded facility for its coastal patrol boats, but also because Australian ships and personnel will be stationed there. While the details remain unclear, some observers have questioned the value of this investment, noting that even with upgrades the port will not be able to accommodate larger vessels (Boyd 2018). At the very least, as Mike Scrafton argued, 'the opportunity costs of building a major facility suited to military operations in a conflict in the Asia-Pacific seem largely unexamined' (2018). Apart from showing support for US hardline policies, the real objective may be to send a muscle-flexing message to Beijing. This move further militarises the conflict and complicates PNG's attempts to balance its relationship with its close neighbour and former colonial power against its significant economic relationship with China.

The Manus base agreement was concluded in the context of escalating tensions in the South China Sea as China makes increasingly clear its intentions to assert control of the area and the US responds equally forcefully (Burgers and Romaniuk 2017). There were diplomatic attempts to draw Pacific Island countries into the dispute in the aftermath of a lawsuit brought by the Philippines against China at the Permanent Court of Arbitration in The Hague. In July 2016 the court found that China's historic claims to sovereignty over most of the South China Sea had no basis in the UN Convention on the Law of the Sea, a judgment that Beijing has adamantly refused to accept (Perlez 2016). China reportedly attempted to 'whip up support' for its legal claims from its Pacific Island allies, although there is no evidence to suggest that anything more than diplomatic encouragement was involved and, in the end, only one country, Vanuatu, publicly indicated support for China's position (Flitton 2016). ${ }^{7}$

7 If conditionality were to be involved in future interactions, however, that would signal a significant change in the political dimensions of China's win-win, no-strings-attached approach to bilateral relations. Especially given their own vested interest in Law of the Sea questions, escalating Chinese pressure would increase demands on Island governments as they walk a diplomatic tight rope between competing powers. 


\section{Taiwan tensions}

A major concern with implications for the Pacific Islands region is that the complex triangular relationship between China, Taiwan and the US will deteriorate further and even lead to overt conflict. The four Pacific Island countries that still recognise Taiwan (Palau, Marshall Islands, Tuvalu and Nauru) are already caught up in this dispute and the pressure to switch allegiance to Beijing is mounting. Indeed, two of Taiwan's former Pacific allies, Solomon Islands and Kiribati, decided to switch recognition to Beijing in September 2019.

Relations between Taipei and Beijing worsened after President Tsai Ingwen and the Democratic Progressive Party came to power in Taiwan in January 2016. Although Tsai repeatedly promised not to seek formal independence, Beijing insisted that she explicitly endorse the ' 1992 consensus', a loose understanding anticipating eventual reunification with China, and exerted considerable economic, diplomatic and political pressure to that end. In a major speech in January 2019, President Xi Jinping claimed that reunification is inevitable, 'the great trend of history', and in the face of any independence attempts China made 'no promise to abandon the use of force, and retain the option of taking all necessary measures' (Buckley and Horton 2019). US President Donald Trump did not help matters when, after his inauguration in early 2017, he accepted a congratulatory phone call from President Tsai and indicated that he might reconsider the US's longstanding acceptance of the One China policy. In March 2018 he signed legislation that encouraged official exchanges with Taiwan and in June opened a new (unofficial) embassy in Taipei. US warships periodically sail through the Taiwan Strait, further demonstrating US support for Taipei (ibid.). Potentially significant for Pacific Island countries is the Asia Reassurance Initiative Act, signed into law in December 2018, which includes a commitment 'to counter efforts to change the status quo' regarding Taiwan.

Pacific Island countries are directly involved in the battle for diplomatic recognition as Beijing moves aggressively to reduce Taipei's international space by cutting off third-party support. Tsai's election in 2016 spelled the end of the eight-year 'diplomatic truce', an informal agreement between Beijing and Taipei to suspend competition for recognition. Since then, seven countries, including two in the Pacific (Burkina Faso, Dominican Republic, Panama, Sao Tome and Principe, El Salvador, Solomon Islands 
and Kiribati) have switched their recognition from Taiwan to China, leaving a total of only 15 countries supporting Taipei. As the balance of power between China and Taiwan shifted decisively in favour of Beijing in recent years, the struggle for recognition is arguably now more about symbolism than substance. Yet it continues to have real consequences, not least because of US interest in the matter. El Salvador's switch in August 2018 elicited a sharp response from the White House, which issued a statement accusing Beijing of 'apparent interference in the domestic politics of a Western Hemisphere country' and warned that it would have to re-evaluate the US relationship with El Salvador (Sands 2018).

Great power politics were very much in evidence in 2019, after it became apparent that leaders in Solomon Islands were considering abandoning their longstanding relationship with Taiwan in favour of recognising Beijing. In June 2018, a group of leaders, including two cabinet ministers, visited Beijing. Although the trip was described as private, officials in Taiwan interpreted it as 'a negative signal' for Taipei (Strong 2018). In April 2019, newly elected Prime Minister Manasseh Sogavare confirmed that a switch to Beijing was under discussion with his coalition partners (Packham 2019). The domestic debate about a possible switch revolved around the fact that China is the major market for Solomon Islands timber exports and that the economic benefits from developing the relationship further would likely far exceed those provided by Taiwan. Indeed, Prime Minister Sogavare was informed that Beijing would offer a starter aid package worth an estimated US\$500 million in return for diplomatic recognition. This was soon countered by the promise of significantly increased assistance, much of it aimed at infrastructure development, from a consortium of Western countries including Australia, New Zealand, Japan and the US, with White House officials travelling to Honiara to lobby Sogavare directly. US Vice President Mike Pence was also involved in the negotiation (see Kabutaulaka, Chapter 1). Despite this political pressure, however, in September 2019 Sogavare announced that Solomon Islands would recognise Beijing, citing the findings of the Bipartisan Task Force and a report from the Ministry of Foreign Affairs and External Trade (Sogavare 2019). When Solomon Islands announced in September 2019 that it would recognise Beijing, officials in Washington DC, including Pence, were quick to register displeasure (Rampton 2019). Western interests received a further setback less than a week later when Kiribati unexpectedly decided to recognise China, apparently after receiving an offer from Beijing to help upgrade sea and air transport systems (Lee 2019). 
All of this puts an intense spotlight on the Pacific Island countries that continue to recognise Taiwan and now represent more than a quarter of all Taipei's remaining diplomatic allies. The situation is further complicated by the fact that two of those countries, Palau and Marshall Islands, are bound to the US through compacts of free association, suggesting that any attempts to switch allegiance to Beijing could provoke a sharp response from Washington. The first country to feel significant pressure from China has been Palau, which has had a close relationship with Taiwan since Palau achieved independence in 1994. Concerned about its ability to cater for growing numbers of tourists, Palau's government began in 2015 to restrict the number of flights from China, which by then carried more than 50 per cent of all visitors. Beijing responded by instructing travel agents not to book tours to this destination. By 2018, the number of visitors from China had dropped by 45 per cent, with significant consequences for Palau's economy. In August 2017 Palau President Tommy Remengesau Jr said that 'it was not a secret that China would like us ... to switch to them' and other officials speculated that Beijing is trying to shore up its influence ahead of the expiry of compact funding. Some business interests in Palau see the economic advantages of switching recognition to Beijing, but US counter moves seem likely given Palau's strategic location in the 'second island chain' (Lyons 2018; Master 2018).

Similar resistance in Washington might be anticipated if the Marshall Islands decides to recognise China, especially given the location of the Kwajalein missile facility there. It is interesting to note that the FSM is the only one of the compact states to recognise Beijing and has long been considered the least strategically significant of the three. Nevertheless, in light of the fact that the western extremities of the FSM constitute part of the second island chain and Chinese companies have proposed large-scale development projects in Yap, the US will probably expand its efforts to offset increasing Chinese economic influence in FSM when compact renegotiations get under way. There are few current indications that Tuvalu is inclined to move away from its recognition of Taiwan and leaders in Nauru are adamantly opposed to breaking relations with Taipei. 


\section{Economic influence and infrastructure}

Existing concerns that China's growing economic ties to Pacific Island countries threaten Western influence in the region have been exacerbated by the southern expansion of the BRI. China is now the second largest trade partner in the region as a whole and the largest for some Island countries. According to the Lowy Institute's aid mapping project, China's committed aid to the region in 2016 amounted to AU\$277.44 million, making it the second largest regional donor behind Australia (AU\$1.02 billion) (Lowy Institute 2019). China is now Fijis largest aid partner and the second largest for PNG, Tonga, Samoa, Cook Islands and Vanuatu. Perhaps most impressive (and visible) are Chinese commercial ventures in the region, led by Metallurgical Corporation of China's US $\$ 1.6$ billion Ramu nickel-mining venture in PNG as well as a rapidly expanding number of construction contracts held by Chinese companies. Many of these contracts, estimated to be worth in excess of US $\$ 5$ billion, are backed by concessional or commercial loans from China's financial institutions, including the China Export-Import Bank and the China Development Bank.

The massive economic and diplomatic BRI-first announced in 2013 and now involving some 120 countries in Asia, the Middle East and Europeis building what Beijing calls a 'community of common destiny' based on trade and commerce. All the Pacific Island countries that recognise Beijing have signed MOUs for BRI cooperation, including Cook Islands and Niue, both in free association arrangements with New Zealand (Devonshire-Ellis 2019). Although many infrastructure projects in the region predate the launch of the Pacific leg of the BRI's 21st Century Maritime Silk Road, the significance of the initiative is clear. BRI increases incentives for Chinese companies to seek out commercial opportunities in Pacific Island countries as well as opening up new sources of funding for such projects.

Ambivalence towards the BRI in US official circles has turned to hostility in recent years. Critics express concern about development standards and practices and contribute to a narrative that highlights examples of maladministered infrastructure schemes or projects that could enable China's military expansion (Pantucci 2018). Informing many of these concerns, however, are underlying anxieties about the implications of all of this for US economic, political and military influence. Viewed through 
a geopolitical lens, the assumed future success of BRI is seen as a growing challenge to the current order. While officials in the Trump administration generally advocate opposition to BRI as part of the wider confrontation with China, some commentators argue that opposition is counterproductive to Western interests since many participating countries welcome this type of investment. Instead, they advocate 'alternative solutions'. Raffaello Pantucci, for example, celebrates Washington's decision to 'super-charge' the Overseas Private Investment Corporation, making more US funds available for infrastructure projects overseas (2018:4).

Western countries active in the Pacific, particularly Australia, have tended to mimic US attitudes to China's infrastructure initiatives by loudly condemning the construction of what Australia's then minister of international development, Concetta Fierravanti-Wells, called 'useless buildings' and 'roads to nowhere' and raising the possibility that some of this activity is a cover for military expansion (Wyeth 2018:1). Narratives about China's 'debt diplomacy' or 'debt-for-equity' leverage originating elsewhere, particularly in debates about the implications of a Chinese company's takeover of port facilities in Sri Lanka, have also found their way into regional discourse (Abi-Habib 2018). Such assertions persist despite a recent analysis of Chinese-funded projects by the Rhodium Group that found that 'actual asset seizures' as a result of defaults on Chinese debt 'are a very rare occurrence' (Kratz et al. 2019:5). Indeed, Barry Sautman and Yan Hairong argue that in the Sri Lankan case:

The Hambantota port lease was not a result of any inability to service the loans, nor was it a debt-for-equity swap-the Sri Lankan government still owns the port. And funds received for the lease were not used to repay port-related debt, but to pay off more expensive loans, generally to Western entities (2019:4).

Whatever the merits of the Sri Lankan case, arbitrarily projecting generalisations about Chinese lending practices onto situations in the Pacific Islands is problematic. While China, like Western countries, undoubtedly hopes to use economic tools to exert influence, the proposition that Beijing is encouraging Pacific countries to take on unsustainable levels of debt in order to extract concessions remains unsubstantiated. Indeed, such an approach might well be counterproductive in Pacific Island countries where Chinese investment is generally welcomed and where assets sufficiently important to Beijing, including strategic ones, are difficult to identify. As Michael O'Keefe points out, if China really 
wanted to use economic means to undermine Western influence in the region, it has ample instruments at its disposal to do so without resorting to a roundabout scheme of debt leverage (2018:3).

Australia has also followed the US lead by attempting to provide alternatives to Chinese economic initiatives. As then foreign minister Julie Bishop put it, her government would 'compete with China's infrastructure development spree in Australia's neighborhood' ostensibly to help counter threats to their sovereignty (Wroe 2018). Among other initiatives, Australia has announced plans to establish a AU\$2 billion infrastructure bank, increase incentives for Australian companies to bid for contracts in the region, build undersea fibre optic cables for Solomon Islands, Papua New Guinea and Vanuatu, and funding (with New Zealand, Japan and the US) a multibillion-dollar rural electrification project in Papua New Guinea (Packham 2018).

\section{Implications for Pacific Islands' aspirations}

China's heightened profile in the Pacific Islands has been accompanied by a significant expansion in the volume of trade with the region, as well as increased flows of aid and investment to Pacific Island countries that recognise Beijing. Heightened tensions between more established actors in the region and China promise to further accelerate the inward flow of resources. According to a statement by President Xi Jinping before his state visit to Papua New Guinea in November 2018, China's support to the region is intended to help Island countries 'in pursuing development paths suited to their national circumstances' as well as 'contributing to economic growth and people's welfare in this part of the world' (Xi 2018). Prime Minister Scott Morrison described the Step-Up in Australia's relations with the Pacific as 'a new chapter in relations with our Pacific family ... for its own sake, because it's right. Because it's who we are'. The overall goal of Australia's policy towards the Pacific, according to Morrison, is a region that is 'secure strategically, stable economically and sovereign politically' (Morrison 2018). Both these statements are laden with unexamined assumptions about, for example, Xi's link between economic growth and human welfare or Morrison's supposition that open market economies promote stability_or indeed his claim that Australia is an integral part of the Pacific family. 
However, it is more important here to explore what all of this new energy might mean for the aspirations expressed by Pacific Islanders themselves. Although there is no Pacific-wide development plan, it is possible to identify some broad principles and priorities informing recent development discourse in the region. These priorities are captured in the Draft Strategic Plan 2017-2020, produced by the Pacific Islands Development Forum (PIDF), a regional organisation established in 2013 'out of a desire to bring transformative changes in member countries by focusing on the sustainable and inclusive development in the region' (PIDF 2017:4). Although a full analysis is beyond the scope of this chapter, it is worth noting that PIDF was formed explicitly in opposition to existing regional institutions, especially the Pacific Islands Forum (PIF), and, according to its architects, to provide a vision for the region more suited to current circumstances. Even if regional support for PIDF has waned recently, the ideas formulated there have informed changes in the priorities and practices in other regional organisations including the PIF (Fry and Tarte 2015).

Since PIDF was formed largely in opposition to the perceived dominance by Australia and New Zealand of PIF and other regional organisations, it is hardly surprising that a key principle animating the work of PIDF is self-determination. According to the PIDF charter, 'The Pacific should be governed by and for Pacific Islanders' and external powers can participate in PIDF deliberations as observers (PIDF 2015:10, 11). There is also a new emphasis on South-South partnerships in international policy initiatives. A second key value is 'a shared and enduring commitment to Green-Blue Pacific economies, sustainable development and especially poverty eradication' (PIDF 2017:8). Matthew Dornan and his colleagues note that terms like 'blue-green growth', the 'green economy' and the 'blue-green economy' are not used consistently in the region (Dornan et al. 2018). For PIDF, these terms do not suggest a rejection of economic growth per se, although there is explicit recognition of 'the valuation of critical ecological, social, spiritual/cultural assets that are not recognised by the "brown economy" (PIDF 2017:10). Instead, the emphasis is on sustainable forms of growth and development informed by 'green' and 'blue' principles, including 'decarbonised' forms of energy and transport. Finally, the major concern that has animated PIDF from the beginning is climate change and its regional impacts. The strategic plan lists its first objective as 'advocating the very real and pressing significance of climate change for the lives and livelihoods of Pacific Islands and Pacific Islanders' (ibid.:8). This priority was echoed at the PIF meeting in Nauru in 
September 2018, where the leaders adopted the Boe Declaration, which in its opening paragraph reaffirms 'that climate change remains the single greatest threat to the livelihoods, security and wellbeing of the peoples of the Pacific' (Doherty 2018).

Escalating competition for influence in the region has mixed implications for the self-determination aspirations of Pacific Island leaders. The arrival of more development partners has certainly provided leaders with more aid, trade and investment options, and transactions with China are not subject to liberal reform conditions typical of agreements with Western powers. Australia's newly discovered emphasis on infrastructure funding will also be welcomed in the region. On the other hand, and despite Morrison's appeal to Pacific Island family values, the fear is that increased Australian resources will be accompanied by an expectation of increased influence over how those resources are used. Paradoxically, if projects are funded by loans then this can only add to the debt burden routinely decried when the funds come from China. Furthermore, framing the Step-Up initiative in terms of regional security is unlikely to be seen as 'of and for' Pacific Islanders, who generally do not see the rise of China as a threat to their security even though the militarisation associated with the competition for influence may well constitute such a threat (O'Keefe 2019). As discussed above, Western strategic imperatives have already had an impact on the self-determination aspirations of colonised Chamorro communities in Guam and, under certain circumstances, could further restrict sovereign options for citizens of the compact states in Micronesia.

Whether or not the expanding flow of resources into the region associated with increasing competition for influence will help or hinder sustainable development goals prominent on the regional agenda depends to a large extent on how such development is defined and pursued. Much foreign investment flows into natural resource exploitation and large-scale mining, forestry or fishing industries are hardly known for their 'green' or 'blue' characteristics, although they might be managed to limit the resulting environmental damage. The imminent onset of seabed mining in the region raises a whole new set of environmental (and other) issues (Hunter et al. 2018). ${ }^{8}$

8 Access to some likely sites for Pacific seabed mining that lie outside the marine jurisdiction of Pacific Island states is controlled by the International Seabed Authority (ISA). As John Copley (2014) pointed out, the ISA was created 'to administer seafloor mining in international waters, not to ask the question "Is it a good idea?". 
Sustainability in other Pacific sectors is often associated with the employment of 'green' technologies such as solar or wind energy. Given the heavy reliance on imported oil for energy generation in many Pacific Island places, as well as the large number of rural communities without access to electricity, this is clearly a desirable trend. However, it does raise questions about increased dependence on the countries where most of these technologies originate, as well as the environmental costs associated with the manufacture, transport and disposal of such equipment (UCS 2013). In a few parts of the region, like Vanuatu, there is a genuine emphasis in development planning on protecting or strengthening the long-established, sustainable and carbon-free kastom (traditional) economy. But even there the demands for cash incomes sometimes override concerns about resource depletion or ecological change (Dornan et al. 2018).

\section{Implications for climate change concerns}

Pacific Islands' concerns about climate change are fully justified given their relatively fragile ecosystems, as well as their vulnerability to extreme weather events and rising sea levels. Especially in the low-lying atoll states of Kiribati, Tuvalu and the Marshall Islands, salt water intrusion already endangers fresh water supplies and staple food crops, while ocean acidification damages coral reefs and degrades the marine ecosystems upon which local populations depend. Escalating great power competition is likely to increase the threat.

Pacific Island governments are actively implementing measures to adapt to the new circumstances. They have also made it a priority to lobby aggressively at the United Nations for action to mitigate the drivers of climate change, especially greenhouse gas emissions. Pacific leaders played a key role in crafting the 2015 Paris Agreement on action to counter climate change, most notably in working to add to the agreement a limit of 1.5 degrees Celsius above preindustrial global temperatures, even if this was only included as an aspirational target (Carter 2018). Their insistence on this inclusion has proved percipient as an October 2018 Intergovernmental Panel on Climate Change (IPCC) report demonstrates that limiting warming to 1.5 degrees Celsius instead of the 2.0 degrees actually targeted in the Paris Agreement makes a huge difference to the global damage caused by rising sea levels, droughts, floods, extreme 
weather events, reduction in biodiversity, ocean acidification and loss of coral reefs (IPCC 2018). The report also notes that a massive global effort is needed to reduce emissions enough to keep below the 1.5 degrees Celsius threshold, as well as indicating the limited time left (12 years) to do so. As a member of the IPCC working group put it, 'We have pointed out the enormous benefits of keeping to 1.5 degrees Celsius, and also the unprecedented shift in energy systems and transport that would be needed to achieve that' (Watts 2018).

The increased attention to the Pacific Islands region associated with the rise of China and efforts by other countries to contain that rise has led to more resources to support adaptation efforts by Island governments. China has supplied solar energy equipment to some Pacific Island countries and appears willing to do more, while the new Pacific policy positions announced by Australia and New Zealand in 2018 include measures to develop resilience in the face of environmental challenges. The situation regarding climate change mitigation is much less promising. The Trump administration's withdrawal from the Paris Agreement and its commitment to relaxing environmental regulations are unfortunate setbacks for global efforts to limit warming, while Australia's determination to keep exporting coal represents a major political impediment to Canberra's efforts to step up its engagement with the Pacific Islands region. And despite its leading role in the development of alternative energy technologies, and some impressive decarbonising efforts at home, China's emissions are not expected to peak until 2030. In the meantime, China remains the number one producer of greenhouse gases (Geall 2017). ${ }^{9}$ As long as other priorities continue to supersede efforts to deal with the causes of climate change, these 'development partners' can only offer to help alleviate some of the symptoms of this existential threat to Pacific lives and livelihoods. In a report released on the eve of its annual Davos conference, the World Economic Forum (WEF) identified climate change and other environmental concerns as the top global risk for 2020 and noted that intensifying geopolitical rivalry was a major impediment to urgent multilateral mitigation efforts (WEF 2020).

9 For example, Sam Geall argues that 'China's shift away from coal-fired energy has proceeded at a rate that was once unimaginable', but notes that whether Beijing will replicate this success in BRI projects overseas remains unclear (2017:3). 
The global competition discussed in this chapter may well aggravate the situation. China's rise is heavily dependent on capitalist-style growth, albeit with 'Chinese characters', while the US attempts to stimulate its own economic expansion in order to maintain a dominant role in the world. Meanwhile both countries seek to enhance their global influence by advocating growth-oriented development to those people on the planet not yet fully integrated into the global economy, including in Pacific Island countries. Studies show that carbon emissions are closely linked to consumption and economic growth, what Monbiot (2016:9) calls the twin 'motors of environmental destruction' (Granados et al. 2012; Rainey 2019). ${ }^{10}$ Short of some radical rethinking of development priorities on the part of powerful global actors, this appears to be a formula destined to frustrate the chances of achieving the enormous roll back of emissions called for in the 2018 IPCC report. Veteran commentator Cary Huang notes Chinese Premier Li Kegiang's pessimistic assessment of China's recent economic performance and argues that a renewed focus on economic stability will likely overshadow efforts to combat financial risk, poverty and pollution: 'Chasing faster economic growth will inevitably come at the expense' of the three 'critical battles' identified by the leaders in 2017 (2019:6).

Although contributing relatively little to global emissions, Pacific Island countries are not entirely disconnected from the emerging crisis. The region's largest country, Papua New Guinea, is an active participant in the global carbon economy, exporting crude oil since the early 1990s and large quantities of liquefied natural gas since 2014. Together these industries represent some 60 per cent of the value of PNG's exports and contribute significant government revenue. It is also worth noting that the IPCC identifies reforestation as an essential component of all of its four identified pathways to lower emissions, but ongoing deforestation is a feature of many island countries, especially in Melanesia (IPCC 2018). In PNG an estimated 4 per cent of the total area of rainforest existing in 2002 had been cleared (some for oil palm plantations) or logged by 2014, with much higher rates in the logged areas (Bryan and Shearman 2015). Solomon Islands relies heavily on the export of unprocessed round logs,

10 The growth-emissions link was demonstrated in 2018 when emissions rose sharply as the US economy expanded in response to the Trump administration's stimulus measures and despite increased use of non-carbon alternatives in the energy and transportation sectors (Rhodium Group 2019). It is also worth noting that increased military spending was a significant factor in the Trump stimulus package and that the US military is the single largest institutional user of oil as well as the single largest institutional emitter in the world. 
most going to China, and trees are being harvested at rates estimated to be as much as 20 times sustainable levels. Indeed, some commentators suggest that if such rates continue, rainforests in Solomon Islands will be all but gone by 2036 (Global Witness 2018).

Several years after the Paris Agreement was signed, it is hard to be optimistic about the chances of its success. The agreement clearly underestimated the speed and severity of the impacts of climate change. The 2018 IPCC report estimates that carbon pollution would have to be reduced by 45 per cent by 2030 in order to keep warming under the 1.5 degree Celsius red line, compared to a reduction of 20 per cent to achieve the 2.0 degree standard written into the agreement (IPCC 2018). And yet most signatory countries are not on track to meet even the more modest goals agreed to in 2015 . The dominant discourse about the global environmental crisis assumes that current patterns of growth and consumption can not only continue but expand, as long as they are accompanied by the deployment of lowcarbon energy alternatives, more efficient use of limited resources and/or the development of large-scale carbon capture technologies. However, the adequacy of any of these proposed solutions has yet to be demonstrated. For example, the authors of a recent analysis of possible climate change pathways argue that reliance on unproven technologies for large-scale carbon removal 'may well represent an irresponsible and inappropriate gamble' (Lamontagne et al. 2019).

That leaves the main focus on other carbon capture and sequestration initiatives and a radical reduction of global emissions. Some analysts suggest that a 'World War II-scale effort' would be required to implement the necessary economic, social and political changes before it is too late (Rockoff 2016). The chances of this eventuating seem remote, especially as policymakers in Washington and Beijing contemplate the emerging imperatives of a different type of war. At the core of the new Cold War, it seems, is a carbon emissions race with potentially catastrophic global consequences.

\section{Conclusions}

Pacific Island countries are facing some direct consequences of the escalating competition between a rising China and the US with its Western allies. Although most of the sites of intense military competition, such as the South China Sea or the Taiwan Strait, lie outside the region, 
some US-affiliated Pacific islands such as Guam, Commonwealth of the Mariana Islands, Marshall Islands, FSM and Palau are directly implicated, while others, most notably PNG, are drawn in because of their defence links to other Western powers. Meanwhile, those Pacific Island states that still recognise Taipei are under political and economic pressure from China to recognise Beijing, and from the United States and its allies not to contemplate such a shift.

However, the most significant impacts of escalating big-power competition for Pacific Island countries are neither military nor political but economic, demonstrated through increased flows of trade, aid and investment. These new resource flows increase the potential for Island leaders to exercise choice and agency, for the region to 'chart its own course', not least by breaking the monopoly of influence exercised for many years by a small number of Western powers. Yet the dominant development discourse in the region continues to emphasise economic growth, albeit using 'green' and 'blue' tools to achieve it. Whatever the perceived short-term benefits of further integration into the global economy, there are also costs associated with this type of development, including the erosion of cultural and social institutions and values, often revolving around land ownership, that have served these societies well for centuries.

A major cost of the accelerating US-China competition are additional pressures to expand a global economy, whose destructive environmental characteristics are readily apparent, and a growing political impulse to prioritise geopolitical competition over climate change mitigation efforts. In other words, the new Cold War has direct implications for what Pacific leaders have identified as the 'single greatest threat to the livelihoods, security and wellbeing of the peoples of the Pacific' (Doherty 2018).

\section{References}

ABC News 2018. Chinese Military Base in Pacific Would Be of 'Great Concern', Turnbull Tells Vanuatu. Pacific Beat program, 10 April. www.abc.net.au/ news/2018-04-10/china-military-base-in-vanuatu-report-of-concern-turnbullsays/9635742

Abi-Habib, M. 2018. How China Got Sri Lanka to Cough Up a Port. The New York Times, 25 June. 
Aguon, J. 2010. On Loving the Maps Our Hands Cannot Hold: Self-Determination of Colonized and Indigenous Peoples in International Law. 16 Asian Pacific American Law Journal 47.

Bolton, J.R. 2018. Remarks by National Security Advisor Ambassador John R. Bolton on The Trump Administration's New Africa Strategy. Remarks to the Heritage Foundation. Washington DC, 13 December. td.usembassy. gov/remarks-by-national-security-advisor-ambassador-john-r-bolton-on-thetrump-administrations-new-africa-strategy/

Boyd, A. 2018. As Oz Gears Up in Manus, China Says 'Discard Cold War Thinking'. Asia Times, 10 November. asopa.typepad.com/asopa_people/2018/11/as-ozgears-up-in-manUS-China-says-discard-cold-war-thinking.html

Bryan J.E. and P.L. Sherman (eds) 2015. The State of the Forests of Papua New Guinea 2014: Measuring Change Over Period 2002-2014. Port Moresby: University of Papua New Guinea. png-data.sprep.org/system/files/The $\% 20$ State\%20of\%20Forest\%20in\%20PNG\%202014.pdf

Buckley, C. and C. Horton 2019. Xi Jinping Warns Taiwan That Unification Is the Goal and Force Is an Option. The New York Times, 1 January. www.nytimes. com/2019/01/01/world/asia/xi-jinping-taiwan-china.html

Burgers, T. and S. Romaniuk 2017. Will Hybrid Warfare Protect America's Interests in the South China Sea? The Diplomat, 30 March. thediplomat.com/2017/03/ will-hybrid-warfare-protect-americas-interests-in-the-south-china-sea/

Callahan, W. 2016. China's 'Asia Dream': The Belt and Road Initiative and The New Regional Order. Asian Journal of Comparative Politics 1(3):1-18. doi.org/10.1177/2057891116647806

Carter, G. 2018. Multilateral Consensus Decision Making: How Pacific Island States Build and Reach Consensus in Climate Change Negotiations. PhD thesis, ANU. doi.org/10.25911/5c7f93e2c3c08

China Daily 2014. China's Xi Proposes Security Concept for Asia. 21 May. www.chinadaily.com.cn/china/2014-05/21/content_17531900.htm

Copley, J. 2014. Shedding Some Light on the International Seabed Authority. University of Southampton blog: Exploring our Oceans, 9 March. moocs. southampton.ac.uk/oceans/2014/03/09/shedding-some-light-on-theinternational-seabed-authority/

D’Arcy, P. 2016. The Chinese Pacific: An Historical Overview. In M. Powles (ed.), China and the Pacific: The View from Oceania. Wellington: Victoria University Press, 46-52. 
Devonshire-Ellis, C. 2019. China's Belt and Road Initiative in the Pacific Islands. Silk Road Briefing. Dezan Shira \& Associates, 23 May. www.silkroadbriefing. com/news/2019/05/23/chinas-belt-road-initiative-pacific-islands/

Doherty, B. 2018. Australia Signs Declaration Saying Climate Change 'Single Greatest Threat' to Pacific. The Guardian, 6 September. www.theguardian.com/ environment/2018/sep/06/australia-signs-declaration-climate-change-greatestthreat-pacific-islands

Dornan, M., W. Morgan, T.N. Cain and S. Tarte 2018. What's in a Term? 'Green Growth' and the 'Blue-Green Economy' in the Pacific Islands. Asia and the Pacific Policy Studies. Special Issue: The Pacific Islands in the 21st Century 5(3):408-25. doi.org/10.1002/app5.258

Dziedzic, S. 2012. US Pledges More Aid for Strategic South Pacific. ABC News, 1 September. www.abc.net.au/news/2012-09-01/an-us-pledges-aid-to-southpacific-copy/4237938

Flitton, D. 2016. South China Sea Dispute: China Is Trading Aid for Support for Claims. The Sydney Morning Herald, 6 June. www.smh.com.au/world/southchina-sea-dispute-china-is-trading-aid-for-support-for-claims-20160606gpc7qf.html

Frankopan, P. 2019. The New Silk Roads: The Present and Future of the World. New York: Alfred A. Knopf.

Fry, G. 1993. At the Margin: The South Pacific and Changing World Order. In R. Leaver (ed.), Charting the Post-Cold War Order. Colorado: Westview Press, 224-42.

Fry, G. and S. Tarte. 2015. The 'New Pacific Diplomacy': An Introduction. In G. Fry and S. Tarte (eds), The New Pacific Diplomacy. Canberra: ANU Press, 3-19. doi.org/10.22459/npd.12.2015.01

Geall, S. 2017. Clear Waters and Green Mountains: Will Xi Jinping Take the Lead on Climate Change? Analyses, 16 November. Lowy Institute. www.lowy institute.org/publications/clear-waters-and-green-mountains-will-xi-jinpingtake-lead-climate-change

Global Witness 2018. Paradise Lost: How China Can Help Solomon Islands Protect its Forests. Report, 18 October. www.globalwitness.org/en/campaigns/forests/ paradise-lost/

Granados, J.A.T., E. L. Ionides and Ó. Carpintero 2012. Climate Change and the World Economy: Short-run Determinants of Atmospheric CO2. Environmental Science \& Policy 21:50-62. doi.org/10.1016/j.envsci.2012.03.008 
Grossman, D., M. Chase, G. Finin, W. Gregson, J.W. Hornung, L. Ma, J.R. Reimer and A. Shih 2019. America's Pacific Island Allies: The Freely Associated States and Chinese Influence. Santa Monica: RAND Corporation. doi.org/10.7249/rr2973

Harvey, F. 2019. Richer Nations Accused of Stalling Progress on Climate Crisis. The Guardian, 14 December. www.theguardian.com/science/2019/dec/13/ richer-nations-accused-of-stalling-progress-on-climate-crisis

Huang, C. 2019. As China Chases Economic Growth, Pollution and Poverty Will Take a Back Seat. South China Morning Post, 17 March. www.scmp.com/weekasia/opinion/article/3001867/china-chases-economic-growth-pollution-andpoverty-will-take-back

Hunter, J., P. Singh, and J. Aguon. 2018. Broadening Common Heritage: Addressing Gaps in the Deep Sea Mining Regulatory Regime. Harvard Environmental Law Review, 16 April. harvardelr.com/2018/04/16/broadening-common-heritage/

IPCC (Intergovernmental Panel on Climate Change) 2018. Global Warming of $1.5^{\circ}$ C. Special Report of the IPCC. New York: United Nations. www.ipcc. $\mathrm{ch} / \mathrm{sr} 15 /$

Jaipragas, B. 2018. The Tiny Island with a Big Role to Play in US Plans for the South China Sea. South China Morning Post, 3 December.

Kaplan, R. 2019. A New Cold War Has Begun. Foreign Policy, 7 January. foreignpolicy.com/2019/01/07/a-new-cold-war-has-begun/

Karabell, Z. 2018. A Cold War is Coming, and it Isn't China's Fault. Foreign Policy, 31 October. foreignpolicy.com/2018/10/31/a-cold-war-is-coming-and-it-isntchinas-fault/

Kerrigan, K. 2018. Former Palau President: Compact 'The Best Deal'. The Guam Daily Post, 16 November. www.postguam.com/news/local/former-palaupresident-compact-the-best-deal/article_60c04990-e891-11e8-a897-b3c22 f850bc5.html

Kratz, A., A. Feng, and L.Wright 2019. New Data on the 'Debt Trap' Question. Rhodium Group Note, 29 April. rhg.com/research/new-data-on-the-debttrap-question/

Lamontagne, J., P. Reed, G. Marangoni, K. Keller and G. Garner. 2019. Robust Abatement Pathways to Tolerable Climate Futures Require Immediate Global Action. Nature Climate Change 9(4):290-94. doi.org/10.1038/s41558-0190426-8 
Laskai, L. 2018. Why Does Everyone Hate Made in China 2025? Council on Foreign Relations, Net Politics blog, 28 March. www.cfr.org/blog/why-doeseveryone-hate-made-china-2025

Lee, Y. 2019. Taiwan Says China Lures Kiribati with Airplanes after Losing Another Ally. Reuters, 19 September. www.reuters.com/article/us-taiwan-diplomacykiribati/taiwan-says-china-lures-kiribati-with-airplanes-after-losing-anotherally-idUSKBN1W50DI

Lind, M. 2018. Cold War II. National Review, 10 May. www.nationalreview.com/ magazine/2018/05/28/us-china-relations-cold-war-ii/

Lowy Institute 2019. Pacific Aid Map. pacificaidmap.lowyinstitute.org/

Lyons, K. 2018. 'Palau against China!': The Tiny Island Standing Up to a Giant. The Guardian, 8 September.

Master, F. 2018. Empty Hotels, Idle Boats: What Happens When a Pacific Island Upsets China. Reuters, 18 August. www.reuters.com/article/us-pacific-chinapalau-insight/empty-hotels-idle-boats-what-happens-when-a-pacific-islandupsets-china-iduskbn114036

Mastro, O.S. 2019. The Stealth Superpower: How China Hid Its Global Ambitions. Foreign Affairs, January/February. www.foreignaffairs.com/articles/china/chinaplan-rule-asia

McCahill, W.C. 2017. China's 'New Era' and 'Xi Jinping Thought'. The National Bureau of Asian Research, 24 October. www.nbr.org/publication/chinas-newera-and-xi-jinping-thought/

Meick, E., M. Ker and H.M. Chan 2018. China's Engagement in the Pacific Islands: Implications for the United States. Staff Research Report, 14 June. Washington DC: US-China Economic and Security Review Commission. www.uscc.gov/sites/default/files/Research/China-Pacific\%20Islands\%20Staff \%20Report.pdf

Monbiot, G. 2016. The Zombie Doctrine. The Guardian, 16 April. www.mon biot.com/2016/04/15/the-zombie-doctrine/

Monbiot, G. 2018. While Economic Growth Continues We'll Never Kick Our Fossil Fuels Habit. The Guardian, 26 September. www.theguardian.com/ commentisfree/2018/sep/26/economic-growth-fossil-fuels-habit-oil-industry

Morgan, W. 2018. The Indo-Pacific and the Blue Pacific. Devpolicy Blog, 22 August. www.devpolicy.org/the-indo-pacific-and-the-blue-pacific-20180822/ 
Morrison, S. 2018. Australia and the Pacific: A New Chapter. Speech at Lavarack Barracks. Townsville, Queensland, 8 November. www.pm.gov.au/media/ address-australia-and-pacific-new-chapter

O'Keefe, M. 2018. Why China's 'Debt-Book Diplomacy' in the Pacific Shouldn't Ring Alarm Bells Just Yet. The Conversation, 17 May. theconversation.com/ why-chinas-debt-book-diplomacy-in-the-pacific-shouldnt-ring-alarm-bellsjust-yet-96709

O'Keefe, M. 2019. Morrison's Vanuatu Trip Shows the Government's Continued Focus on Militarising the Pacific. The Conversation, 17 January. theconversation. $\mathrm{com} /$ morrisons-vanuatu-trip-shows-the-governments-continued-focus-onmilitarising-the-pacific-109883

Olson, W. 2019. US Soldiers Return to Palau after 37 Year Hiatus. Stars and Stripes. Military.com, 8 April. www.military.com/daily-news/2019/04/08/us-soldiersreturn-palau-exercise-after-37-year-hiatus.html

Packham, B. 2018. Canberra to Fund PNG Internet and Electricity Boost. The Australian, 14 November. www.theaustralian.com.au/national-affairs/ foreign-affairs/canberra-to-fund-png-internet-and-electricity-boost/news-sto ry/652c21a086fc76a21f0c2d73b6edc8dc

Packham, B. 2019. China Eyes Pacific Alliance with the Solomon Islands. The Australian, 1 May. www.theaustralian.com.au/nation/politics/china-eyespacific-alliance-with-the-solomon-islands/news-story/7b9f0830b8d083054 bb998ae22a221ff

Panda, A. 2018. Are Fears of a Chinese Port Facility on Manus Island Justified? The Diplomat, 29 August. thediplomat.com/2018/08/are-fears-of-a-chineseport-facility-on-manus-island-justified/

Pantucci, R. 2018. China’s Belt and Road Hits Problems but Is Still Popular. Financial Times, Beyond BRICS blog, 15 November. Available at raffaello pantucci.com/2018/11/28/chinas-belt-and-road-hits-problems-but-is-stillpopular/

Pence, M. 2018. Remarks by Vice President Pence on the Administration's Policy Toward China. Washington DC: The Hudson Institute, 4 October. china.usembassy-china.org.cn/remarks-by-vice-president-pence-on-theadministrations-policy-toward-china/

Perlez, J. 2016. Tribunal Rejects Beijing's Claims in South China Sea. The New York Times, 12 July. www.nytimes.com/2016/07/13/world/asia/south-chinasea-hague-ruling-philippines.html 
PIDF (Pacific Islands Development Forum) 2015. Charter of the Pacific Islands Development Forum. Suva: PIDF. www.pidf.int/wp-content/uploads/2017/ 07/PIDF-Charter.pdf

PIDF (Pacific Islands Development Forum) 2017. Draft Strategic Plan, 20172020. Suva: PIDF. www.pidf.int/wp-content/uploads/2017/07/PIDF-StrategicPlan.pdf

Rainey, J. 2019. Economic Expansion Boosts Carbon Emissions, Despite GreenTech Gains. NBC News, 9 January. www.nbcnews.com/news/us-news/ economic-boom-spikes-carbon-emissions-despite-green-tech-gains-n956336

Rampton, R. 2019. Pence Rebuffs Solomon Islands PM after Nation Cuts Ties with Taiwan. Reuters, 17 September. www.reuters.com/article/us-taiwandiplomacy-pence-exclusive-idUSKBN1W22WK

Rhodium Group 2019. Preliminary US Emissions Estimates for 2018. Rhodium Group Note, 8 January. rhg.com/research/preliminary-us-emissions-estimatesfor-2018/

Rockoff, H. 2016. The US Economy in WWII as a Model for Coping with Climate Change. National Bureau of Economic Research Working Paper no. 22590. www.nber.org/papers/w22590

Roy, D. 2014. US-China Relations and the Western Pacific. The Diplomat, 16 January. thediplomat.com/2014/01/US-China-relations-and-the-westernpacificl

Sands, G. 2018. Even with US Help, Taiwan Is Fighting a Losing Battle Against China to Keep its Friends and Influence. South China Morning Post, 13 September. www.scmp.com/comment/insight-opinion/united-states/ article/2164009/even-us-help-taiwan-fighting-losing-battle

Sautman, B. and Y. Hairong 2019. The Truth About Sri Lanka's Hambantota Port, Chinese 'Debt Traps' and 'Asset Seizures'. South China Morning Post, 6 May. www.scmp.com/comment/insight-opinion/article/3008799/truth-about-srilankas-hambantota-port-chinese-debt-traps

Scrafton, M. 2018. What War Will We Need Manus For? The Strategist, 4 December. Australian Strategic Policy Institute. www.aspistrategist.org.au/ what-war-will-we-need-manus-for/

SIPRI (Stockholm International Peace Research Institute) 2019. World Military Expenditure Grows to $\$ 1.8$ Trillion. SIPRI media release, 29 April. www. sipri.org/media/press-release/2019/world-military-expenditure-grows-18trillion-2018 
Sogavare, M. 2019. Statement by the Prime Minister Hon. Manasseh Sogavare on Switch to China. Solomon Times, 20 September. www.solomontimes.com/ news/statement-by-the-prime-minister-hon-manasseh-sogavare-on-switchto-china/9362

Spinelli, D. 2019. These Trump Allies Are Preparing for a New Cold War with China. Mother Jones, 22 April. www.motherjones.com/politics/2019/04/thesetrump-allies-steve-bannon-frank-gaffney-new-china-cold-war/

Strong, M. 2018. Officials from Taiwan Ally Solomon Islands Visit China. Taiwan News, 16 June.

Sutter, R. 2018. China-Russia Relations: Strategic Implications and U.S. Policy Options. NBR Special Report no. 73. The National Bureau of Asian Research. www.nbr.org/publication/china-russia-relations-strategic-implications-andu-s-policy-options/

Talmadge, C. 2018. Beijing's Nuclear Option; Why a U.S.-Chinese War Could Spiral Out of Control. Foreign Affairs, November/December: 44-50.

Tarabay, J. 2018. CIA Official: China Wants to Replace US as World Superpower. CNN, 21 July. www.cnn.com/2018/07/20/politics/china-cold-war-us-super power-influence/index.html

Tarapore, A. 2018. The Geopolitics of the Quad. The National Bureau of Asian Research, 16 November. www.nbr.org/publication/the-geopolitics-of-thequad/

Tong, A. 2015. 'Charting its Own Course': A Paradigm Shift in Pacific Diplomacy. In G. Fry and S. Tarte (eds), The New Pacific Diplomacy. Canberra, ANU Press, 3-19. doi.org/10.22459/npd.12.2015.02

UCS (Union of Concerned Scientists) 2013. Environmental Impacts of Renewable Energy Technologies. UCS blog, 5 March. www.ucsusa.org/clean-energy/ renewable-energy/environmental-impacts

Underwood, R.A. 2017. The Changing American Lake in the Middle of the Pacific. Address at Georgetown University, 16 November. www.uog.edu/_resources/ files/news-and-announcements/2017-2018/robert-underwood-the_changing american_lake-111617.pdf

USCC (US-China Economic and Security Review Commission) 2018. 2018 Report to Congress. Washington, DC: US-China Economic and Security Review Commission, November. www.uscc.gov/annual-report/2018-annualreport-congress 
US Government (Department of Defense) 2019. Indo-Pacific Strategy Report: Preparedness, Partnership, and Promoting a Networked Region. Washington DC: Department of Defense, 1 June. media.defense.gov/2019/Jul/01/2002152311/1/-1/1/DEPARTMENT-OF-DEFENSE-INDO-PACIFIC-STRATEGYREPORT-2019.PDF

Walt, S. 2018. What Sort of World Are We Headed For? Foreign Policy, 2 October. foreignpolicy.com/2018/10/02/what-sort-of-world-are-we-headed-for/

Watts, J. 2018. We Have 12 Years to Limit Climate Change Catastrophe, Warns UN. The Guardian, 8 October. www.theguardian.com/environment/2018/ oct/08/global-warming-must-not-exceed-15c-warns-landmark-un-report

WEF (World Economic Forum) 2020. The Global Risks Report 2020. 15th edition. Geneva: WEF. www.weforum.org/reports/the-global-risks-report-2020

Wesley-Smith, T. 2013. China's Rise in Oceania: Issues and Perspectives. Pacific Affairs 82(2):351-72. doi.org/10.5509/2013862351

Wesley-Smith, T. 2016. Geopolitics, Self-Determination, and China's Rise in Oceania. In M. Ishihara (ed.), Self-Determinable Development of Small Islands. Singapore: Springer, 85-99. doi.org/10.1007/978-981-10-0132-1_5

White, H. 2017. Without America: Australia in the New Asia. Quarterly Essay 68:1-81. www.quarterlyessay.com.au/essay/2017/11/without-america

White, H. 2019. Can the US Win the New Cold War with China? Not without Risking a Nuclear War. South China Morning Post, 6 March. www.scmp.com/ comment/insight-opinion/united-states/article/2188648/can-us-win-newcold-war-china-not-without

Woodward, J. 2017. The US vs China: Asia's New Cold War? Manchester: Manchester University Press.

Wroe, D. 2018. Australia Will Compete with China to Save Pacific Sovereignty, Says Bishop. The Sydney Morning Herald, 18 June. www.smh.com.au/politics/ federal/australia-will-compete-with-china-to-save-pacific-sovereignty-saysbishop-20180617-p4zm1h.html

Wyeth, G. 2018. Is China Building Roads to Nowhere in the Pacific? The Diplomat, 17 January. thediplomat.com/2018/01/is-china-building-roads-to-nowherein-the-pacific

Xi, J. 2018. Jointly Charting a Course Towards a Brighter Future. Speech at APEC CEO Summit, Port Moresby, Papua New Guinea. Xinhua, 17 November. www.xinhuanet.com/english/2018-11/17/c_137613904.htm 
Yale News 2018. We May Be Underestimating Future Economic Growth, and its Potential Climate Effects. 14 May. news.yale.edu/2018/05/14/we-may-beunderestimating-effects-economic-growth-climate-change

Zhang, D. 2018. China, India and Japan in the Pacific: Latest Developments, Motivations and Impact. DPA Discussion Paper 2018/6. Canberra: ANU. dpa. bellschool.anu.edu.au/sites/default/files/publications/attachments/2018-09/ dpa_dp2018_6_zhang_final.pdf 
This text is taken from The China Alternative: Changing Regional Order in the Pacific Islands, edited by Graeme Smith and Terence Wesley-Smith, published 2021 by ANU Press, The Australian National University, Canberra, Australia.

doi.org/10.22459/CA.2021.02 